\title{
Thulia: a Tale of the Antarctic (1843): The earliest Antarctic poem and its musical setting
}

\author{
Elizabeth Truswell ${ }^{1}$
}

Thulia: a Tale of the Antarctic is a long narrative poem written by James Croxall Palmer, assistant surgeon to the United States Exploring Expedition of 1838-42. The poem was first published in 1843, shortly after the completion of that epic and controversial voyage.

I suggest that this represents the first poem about Antarctica as we know that continent in its essentially modern sense. Coleridge's Rime of the Ancient Mariner obviously has strong claims to priority in the poetry of the extreme southern regions, because it was first published in 1798, after, and probably inspired by, James Cook's second voyage of 1772-75. But when Coleridge's poem appeared there was little sense of a substantial continent. In the Rime Antarctica is implied — an icy and a terrifying presence — rather than mentioned. While Cook was the first to penetrate southward below the Antarctic Circle, and, in his lengthy and well-documented voyage, to circumnavigate the polar continent, he did not discover it in any spatial sense. Indeed, he was aware himself of the limitations of his achievement in terms of his commission to search for the near-legendary Southern Continent. In his Journal, Cook wrote, 'I had now made a circuit of the Southern Ocean in a high latitude and traversed it in such a manner as to leave not the least room for the Possibility of there being a continent, unless near the Pole and out of the reach of Navigation ... That there may be a continent or large tract of land near the Pole, I will not deny'. ${ }^{2}$

Other voyagers followed in the early part of the 19th century. They were largely sealers and whalers, some of whom had a scientific as well as a commercial bent. But their footholds were tenuous, their sightings fragmentary and disconnected. It was not until the United States Exploring Expedition in 1840 traversed some 2,400 kilometres of ice-bound coastline that the presence of something akin to a major continent was established in the region of the South Pole.

My encounter with James Palmer's poem comes from my own experience of Antarctica. I have been writing an account of voyaging with the Deep Sea

\footnotetext{
1 Dr Elizabeth Truswell, Visiting Fellow, Research School of Earth Sciences, The Australian National University, Canberra ACT 0200, etruswell@aapt.net.au.

21 February 1775. James Cook (2003) The Journals. Prepared from the original manuscripts by JC Beaglehole for the Hakluyt Society, 1955-67, edited by Philip Edwards. Penguin, London, p. 414.
} 
Drilling Project, which from the 1970s has sought to establish the history of the Antarctic icecap and the associated climatic changes. In the course of that project, in search of geological evidence for the oldest ice, a site was drilled into the ocean floor, close to the edge of Antarctica, lying off the region known as the Knox Coast. In searching for the origin of that name, I discovered that it was named for a member of the US Exploring Expedition, a 'Passed Midshipman' named Samuel Knox, who was the first to command the schooner Flying Fish. ${ }^{3}$ This led me to look much more deeply into that controversial expedition, which was when I came across the poem.

The United States Exploring Expedition of 1838-42 was America's attempt to catch up with what were known to have been, or about to be, expeditions to the south launched from Europe - expeditions such as that of the British under the command of James Clark Ross in Erebus and Terror, and the French under Dumont d'Urville, with Astrolabe and Zélée.

The US Exploring Expedition (often referred to - but without affection - as the Ex.Ex. or the Wilkes Expedition) had a long and difficult birth, but was eventually approved by President John Adams, and Lieutenant Charles Wilkes was selected as Commander. Wilkes was certainly not the first choice, and possibly not the best, as subsequent events were to prove. The expedition's aims were many and diverse: to seek new territories in the South Seas, to protect US sealing and whaling industries, to look for new opportunities for commerce, to assert American power, and to undertake scientific research in a wide range of disciplines.

The expedition consisted of six vessels, aptly described as 'oddly assorted'. The flagship was the USS Vincennes, a sloop-of-war of the US Navy. Other large vessels were the Peacock, also a sloop-of-war; the brigantine Porpoise; the clumsy sailer Relief, which served as a supply ship; and bringing up the rear of the squadron, two tiny vessels, the Flying Fish and the Sea Gull, both former New York pilot boats. These last were certainly small, and ill-equipped for dealing with the rigours of Antarctic waters. The Flying Fish was a sloop of a mere 96 tons, often with a crew of less than ten.

Indeed, none of the vessels of the expedition had been modified to deal with the expected conditions. None had the double-planked hulls, the sturdy oaken keels and waterproof decking that had been fitted, for example, to the vessels of the British expedition under James Clark Ross.

Some nine scientists were appointed to the expedition. Wilkes had significantly reduced this number from a larger contingent originally proposed. The civilian

3 Nathaniel Philbrick (2003) Sea of glory: America's voyage of discovery, the US Exploring Expedition 1838-1842. Viking, New York. 
scientific corps eventually consisted of naturalists, a botanist, a mineralogistgeologist, taxidermists, and a philologist or linguist. Wilkes elected to undertake the surveying and hydrography himself. The one member of this party who eventually enjoyed scientific fame was the geologist James Dwight Dana, who is essential to the present story. The Assistant Surgeon to the expedition was one James Croxall Palmer. The scientists - the 'scientifics' - didn't rate very highly with Wilkes. None of them were actually included in the Antarctic parts of the venture - they were kept apart and allowed to work in the Pacific.

The expedition left from Norfolk, Virginia, on 19 August 1838. The vessels sailed across the Atlantic to Madeira and the Cape Verde Islands, and then recrossed that ocean to voyage down the coast of South America, eventually to shelter in Orange Bay, on the southern coast of Tierra del Fuego. From there with the assemblage of ships divided into two - they were to make the first attempt into the Antarctic. Their timing for this venture was poor, as the brief summer season was nearing its end. The aim was to achieve 'furthest South' to venture further than either James Cook in 1774, or the sealing captain James Weddell in 1823. The Peacock and the tiny Flying Fish took the route in search of Cook's record - Cook's ne plus ultra, which lay to the west of the Antarctic Peninsula. The Porpoise and the Sea Gull followed Weddell's route to the east, but were driven back by impenetrable ice.

The Flying Fish almost reached Cook's most southerly point — but, reaching $70^{\circ} \mathrm{S}$ latitude, fell just a degree short. The Peacock and the Flying Fish were separated, and the Flying Fish crew in particular faced a battle against ice and storms - with huge seas, giant icebergs and ice floes - losing most of the sails and masts in the tumultuous conditions. Eventually they struggled back to Orange Harbour. The other small sloop, the Sea Gull, was lost forever in severe storms when the vessels of the expedition were leaving that refuge on the next leg of their voyage.

The remaining ships of the Ex.Ex. sailed into the Pacific, and carried out surveying, scientific and ethnographic studies of a multitude of oceanic islands. Then, from a base in colonial Sydney, they made another attempt on the Antarctic, sailing south on 26 December 1840, at the height of the southern summer. After encountering the ice-bound margin of East Antarctica, the vessels turned westwards and traversed some 2,400 kilometres of that hazardous coast.

The sighting of land was reported on several occasions - some of the sightings were controversial, poorly recorded in the ship's log and subsequently contested - and no landings were made. Later explorers, including Douglas Mawson, were dismayed to find that in places Wilkes' calculations had been in error by over 100 kilometres in latitude, due probably to the phenomenon of 'looming', where the refraction of light makes it possible to see objects lying far below the 
horizon. Nevertheless, where Wilkes had been able to get closer to the coast, his sightings were accurate, his measurements of longitude remarkably sound. Before retreating northwards at the long glacier they called 'Termination Tongue' - now considered part of the Shackleton Ice Shelf - Wilkes felt justified in claiming to be the first to establish Antarctica as a major continent, rather than isolated and disconnected islands. The legacy of the voyage was long-lasting; mariners around the world used many of Wilkes' charts for more than a century.

The magnitude of the achievements of the Ex.Ex., however, tended for some years to be overshadowed by the court martial brought against Wilkes by his subordinates, on the grounds of ill treatment of his junior officers. While these accusations were not upheld, and the claims of the officers were eventually dismissed, the doubts raised by the court martial lingered, and explorers such as James Clark Ross refused to accept the findings of Wilkes' survey.

\section{The fate of the Peacock}

The expedition returned to the US, in fulfilment of its commission to map part of the northwestern coast of North America - the region around the mouth of the Columbia River. There, the large ship Peacock foundered on a sand bar at the mouth of the river, and was lost, broken up by the waves. The crew, miraculously, was saved.

\section{James Croxall Palmer and the poem Thulia}

On board the Peacock at this stage was James Croxall Palmer (1811-1883), appointed then as Assistant Surgeon to the expedition. Palmer was a thoroughgoing medical man. He later served in a variety of vessels, and was involved in naval battles of the American Civil War. Subsequently, he enjoyed a distinguished career as head of a number of naval hospitals, eventually becoming Surgeon General of the US Navy. 


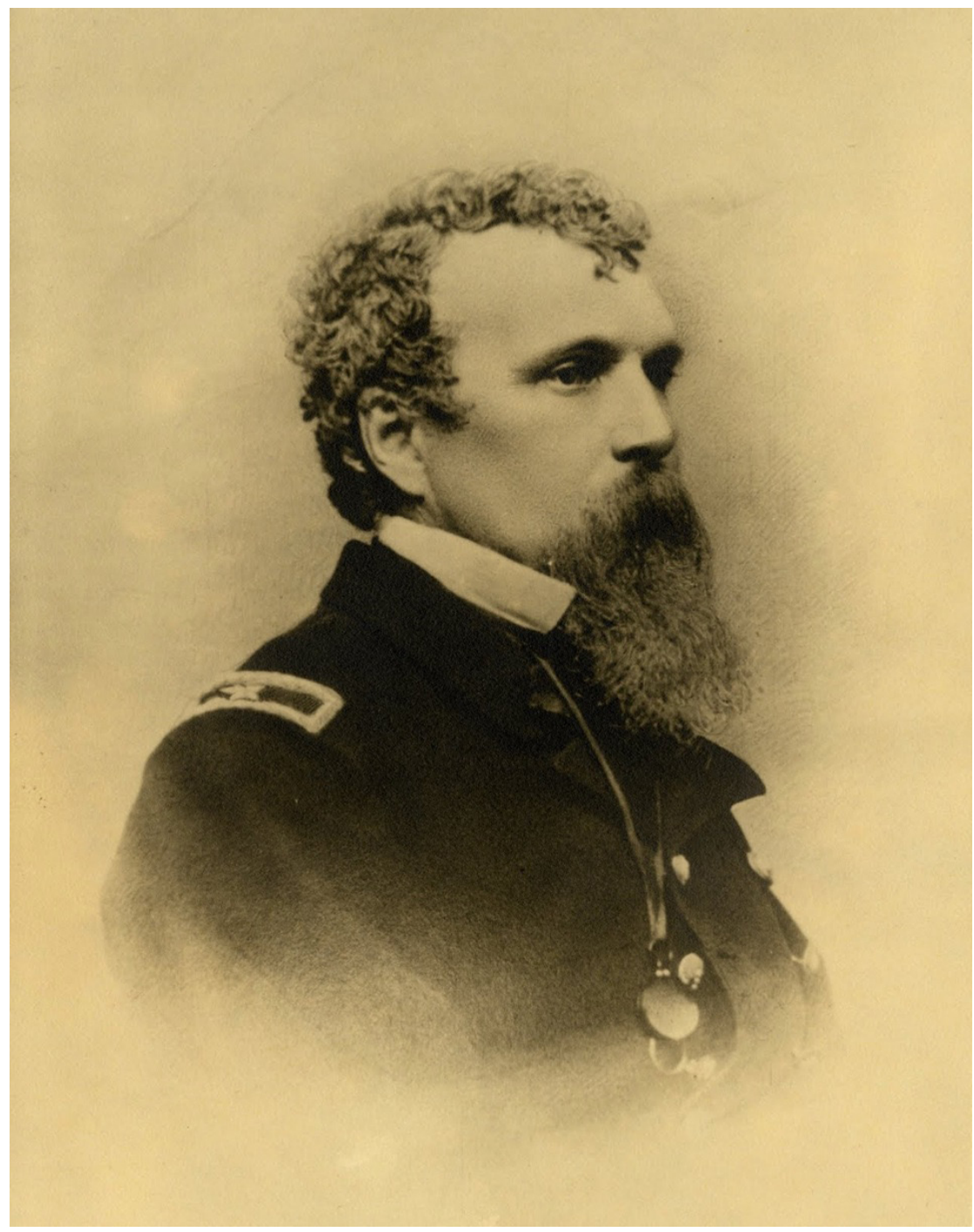

Figure 1. James Croxall Palmer.

Source: Photograph reproduced by permission of the US Bureau of Medicine and Surgery.

Along with other officers, Palmer had kept a meticulous record of the events of the voyage in his journal. That journal was lost in the shipwreck, but Palmer was able to recall, in fine detail, the events, not only of the Peacock, but many of the struggles that had beset the other vessels.

Palmer was also a poet. In 1843, just a year after the completion of the Ex.Ex. expedition, he published the epic poem that he had begun during the Antarctic venture - this he called Thulia: a Tale of the Antarctic. In the poem, the tiny vessel Flying Fish becomes Thulia - a reference to Thule, an island in antiquity, or any far-off region beyond the borders of the known world, though the term 
has historically had a northern connotation. Palmer dedicated the volume to Lieutenant William M Walker, commander of the Flying Fish during its struggle to reach the sought-after furthest South. (It should be noted that Walker's command of the Flying Fish was a temporary assignment as Wilkes, ever concerned that cabals might be developing against his leadership, frequently changed the officers in command of the ships of the expedition. Samuel Knox first commanded the vessel). In the preface to Thulia, Palmer offered the following explanation:

The following poem is a true story of the incidents more minutely detailed in the Appendix, to which the reader is referred for a narrative prepared for the journals of the Flying Fish. It unfortunately happened that these journals, which had been collected on board the U.S. Ship Peacock, were lost with that vessel at the mouth of the Columbia: so that the account which I wrote only for the gratification of a few friends, has become the sole remaining history of a highly interesting adventure. ${ }^{4}$

The poem itself is a long, book-length epic in characteristic ballad form, most of it in four-line stanzas with a simple $a-b-a-b$ rhyme pattern. The volume is illustrated with 12 engravings, contributed by the expedition's able young artist, Alfred Agate.

Palmer may well have been aware of the Rime of the Ancient Mariner, but he was certainly no Coleridge! There is, as might be expected, a mix in the poem of high adventure, vivid imagery, idealism, terror, and a longing for the softer climes of home. There is too a clear theme of patriotism - the search for glory in the name of America.

The language of the poem is essentially simple, populist perhaps. It oscillates between a form of reality about nature, and a simple romanticism. According to the American scholar William Lenz, Palmer uses 'simple, familiar literary forms to domesticate the Antarctic'. ${ }^{5}$ The landscape it describes lacks the ominous presence of the supernatural, so evident in Coleridge's epic.

Within Thulia there are some separate poems. These seem to sit oddly, interrupting the flow of the ballad. The Antarctic Mariner's Song, for instance, is one such, with its theme of national glory. The Bridal Rose is another poem, a story of romantic love based on an 'adventure' on board the Peacock (presumably in the Pacific). This lack of unity in the poem's structure, as noted by Lenz, may reflect the occasional nature of the composition, and the difficulty that Palmer had, perhaps, as a non-professional writer, in sustaining a long work. 
With its publication in 1843 - some said in time to catch the Christmas market - this poem was in fact the first narrative of the voyage to appear in print after the return of the expedition. The notes and appendix to the poem support the verses with a remarkably full description of the quest for furthest south.

Wilkes had appropriated for himself the writing of the official account of the expedition, drawing both on his own journals and on those of his officers. His five-volume narrative of the voyage was published with funding by the US Congress in 1844, two years after the end of the expedition, and just one year after the publication of Thulia. Palmer's epic poem thus neatly pre-empted his commander's effort; its quick publication suggests that it slipped under his radar. It may be that Wilkes did not recognise it for what it was - and thought it to be just a romantic poem, rather than a revealing story describing significant parts of the expedition's voyage.

Palmer published a second edition of the poem in 1868, when he was head of the naval hospital in Brooklyn, New York. ${ }^{6}$ This he titled The Antarctic Mariner's Song. Some new poems were added in this second version, including a rollicking sea-shanty, The Air from the Icebergs, detailing an event in which the rudder of the Peacock was splintered and almost lost in a rear-end collision with an iceberg during the long voyage around the coast of Antarctica.

Sentimentality characterises some of the newly added poems; Monody, for example, reflects on the death of a child whose father is away on the exploring expedition. Other verses in this edition are more introspective, perhaps viewing the experience of the voyage from the perspective of 25 years. In this edition, Palmer also made many minor changes to the wording of the original stanzas of Thulia. He carried out extensive 'tinkering', substituting some words and changing word order.

There are minor differences too in the illustrations; one engraving, The ice islands, has been added, with its emphasis on the human presence in a landscape that overwhelms. Others, particularly those that focus on details of life on board the vessels, have been enlarged to occupy a greater prominence.

The following extracts give a brief overview of the language, structure, and themes of Thulia. First, the narrative verses give the Antarctic setting, and the former role of the tiny Flying Fish as a pilot boat on the Hudson River.

I.

Deep in a far and lonely bay,

Begirt by desert cliffs of snow,

A little bark at anchor lay,

6 James Croxall Palmer (1868) Antarctic mariner's song. Van Nostrand, New York. 
In southern twilight's fiery glow.

Too frail a shell - too lightly borne

Upon the bubble of a wave,

To face the terrors of Cape Horn,

Or stern Antarctic seas to brave.

In other days she loved to glide

O'er Hudson's bosom bright and still;

And float along the tranquil tide,

By craggy steep and sloping hill.

Now, like a land-bird, blown away

By tempests from its happy nest,

She flies before the whirling spray,

To seek this dreary place of rest.

From time to time, a clearly patriotic theme comes through - never more strongly than in The Antarctic Mariner's Song, from which the following verses are taken:

I.

Sweetly, from the land of roses

Sighing comes the northern breeze;

And the smile of dawn reposes,

All in blushes, on the seas.

Now within the sleeping sail,

Murmurs soft the gentle gale.

Ease the sheet, and keep away:

Glory guides us South today...

IV.

Circled by these columns hoary,

All the field of fame is ours;

Here to carve a name in story,

Or a tomb beneath these towers.

Southward still our way we trace,

Winding through an icy maze.

Luff her to - there she goes through!

Glory leads, and we pursue.

Between two icebergs gaunt and pale,

Like giant sentinels on post;

Without a welcome or a hail,

Intrude they on the realm of Frost. 
In desolation vast and wild,

Outstretched a mighty ruin lies:

Huge towers on massy ramparts piled:

High domes whose azure pales the skies.

Although some of Palmer's images verge on the gothic ('giant sentinels', 'huge towers' and 'massy ramparts', for instance), 'they carry no metaphysical threat, invoke no curse or dread, conjure up no spiritual horror as in Coleridge, Shelley or Poe. They are in fact comfortably familiar literary images' ${ }^{7}$

The appendix to the poem is in part notes to the text, explaining the realities of some of the poetic references, and including the very real accounts of the voyage. In this, Palmer confesses the difficulty he has with the Romantic and the Real.

It is clear from this that Palmer is negotiating the demands of poetry, travelogue and scientific reporting. The notes before the appendix offer scientific explanations for some of the romantic images in the poetry. In these Palmer mixes poetic expression and science - he seems to be driven by a need to explain himself - to validate the poetry with contemporary science. He thus seems to be vacillating between his roles as a poet and as a member of a huge scientific expedition.

Selected verses demonstrate this mix of romance and reality.

O'er mounds of vapour daily rolled,

Huge castled clouds are towering high,

Confronting with the billows bold,

That dash defiance to the sky.

(Palmer 1843, p. 21)

And with the roving albatross,

The sheath-bill flickers round and round;

And petrels hop the foam across,

Where lightest janthine might be drowned.

(Palmer 1843, p. 23)

In these verses the scientific observations creep in. The line 'Huge castled clouds are towering high' comes from the journal of Captain Fitzroy of the Beagle, who reported that these clouds or cumuloni were peculiar to the waters around Cape Horn, and came up with the south-west gales.

7 Lenz (1995) The poetics of the Antarctic. 
The second of the above verses is dense with biological references. First, a brief rollcall of bird life. After the albatross comes reference to the sheathbill probably the Snowy Sheathbill of Antarctic waters and islands - then to the petrel, which could refer to any one of a range of species, but which are mostly distinguished by low flight skimming across wave surfaces, hence they 'hop the foam across'.

Then there is 'janthine' - surely a curious word in a romantic poem of this era. The reference here is probably to Janthina janthina, the fragile purple sea snail, often found washed up on southern beaches. This gastropod of the open oceans builds a little raft of bubbles to float on the sea surface; its shell colour is light above and dark below, so that sea-birds passing overhead find it difficult to detect, a fact that Palmer notes.

Lenz doesn't speculate on the relationships that Palmer may have had with the 'scientifics' of the expedition, nor do the journals of other expedition members offer enlightenment. Was his awareness of details of the science heightened by his interest in their discoveries? Did he feel that his link with a scientist already as eminent as, for example, James Dana, would help to legitimise his poetry? Given that Palmer would have shared an educated background with members of the scientific party, it is not unexpected that he would have chosen them as companions on the voyage, and been a party to the discussion of their scientific endeavours.

\section{James Dwight Dana and the musical setting of Thulia}

Not only does the original poem - the epic of Thulia - have claims to be the oldest Antarctic poem, it also includes what is probably the first Antarctic music. It is here that James Dwight Dana comes into the story. Dana, just a few years younger than Charles Darwin, had produced his System of mineralogy by the age of 24. Published to wide acclaim in 1837, this book is, amazingly, essentially still a standard text today, with more than 22 revised and reprinted editions. Dana's interests were wide-ranging. He joined the Ex.Ex. as a geologist and mineralogist, but eventually took responsibility for writing the reports on zoology, as well as those on geology, working on these for 13 years after the end of the expedition. ${ }^{8}$ Included in his report on the Crustacea is the first

8 James D Dana (1846) Zoophytes. United States Exploring Expedition, vol. 7. C Sherman, Philadelphia; James D Dana (1849) Geology. United States Exploring Expedition, vol. 10. C Sherman, Philadelphia. 
description of krill, the tiny shrimp-like organism that is the base of the food chain for a number of Antarctic ecosystems. ${ }^{9}$ Scientifically, its name remains Euphausia superba Dana 1850.

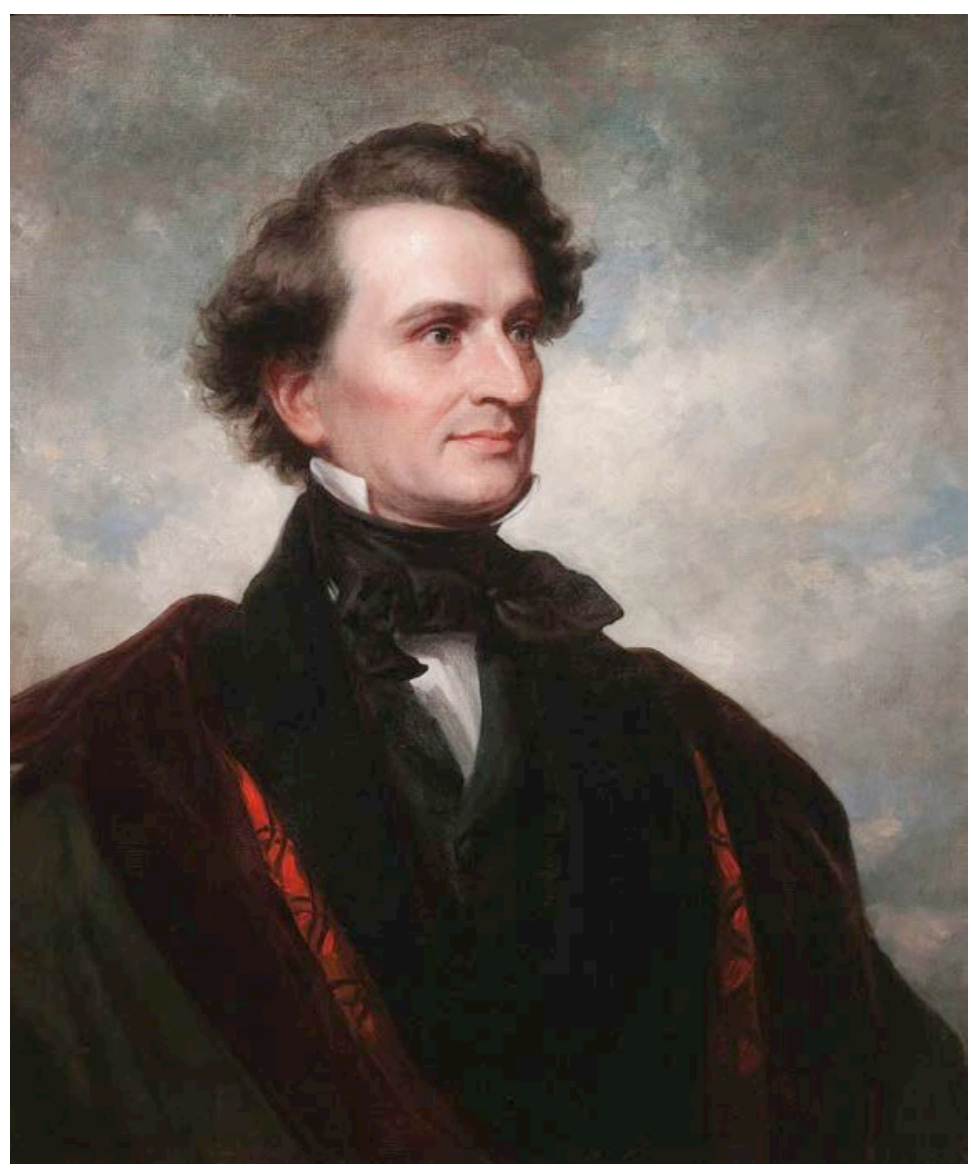

\section{Figure 2. James Dwight Dana.}

Source: Painted by Daniel Huntington, 1858 (Wikipedia Commons).

In his life's work, Dana attempted grand geological syntheses. He wrote a treatise on the origins of coral reefs - basically expanding Darwin's understanding of them, showing that the volcanic islands with which reefs are associated occur in linear chains, reflecting the age progression of the islands. Much of this knowledge derived from his study of the islands of Hawaii. He established the geologic distinction between the composition and dynamics of continents and ocean basins, and the ways in which mountain belts - particularly those of North America - form about the ancient core of a continent. Among his awards

9 James D Dana (1852) Crustacea. United States Exploring Expedition, vols 13, 14. C Sherman, Philadelphia. 
were the prestigious Copley Medal of the Royal Society, the Wollaston Medal of the Geological Society of London, and the Clarke Medal of the Royal Society of New South Wales. Contemporary scientists, including Darwin, heaped praise on Dana's head. Following his work on the Crustacea, but referring too to his work on corals and geology, Darwin wrote to Dana thus, 'I am really lost in astonishment at what you have done in mental labour. And then, beside the labour, so much originality in all your works!' ${ }^{10}$ Alexander von Humboldt, too, referred to him as one of the greatest scientists of the age.

Dana spent three months in New South Wales while the rest of the expedition undertook the voyage to the edge of Antarctica. ${ }^{11}$ The corps of civilian scientists was not to be involved in that part of the voyage, the imperious Wilkes having rationalised that there would be nothing in it to interest them. Wilkes, no doubt, was secretly relieved to be temporarily rid of the 'scientifics', who could not be subjected to his strict naval discipline.

Dana looked forward to his enforced stay in the Australian colony where he 'could gratify ... but partially, in a geological point of view, the curiosity which so strange a land may well excite'. ${ }^{12} \mathrm{He}$ was soon introduced to the Reverend WB Clarke, the 'father of Australian geology'. He travelled with Clarke to the Illawarra, where the two engaged in spirited debate about the origin of river valleys. Later, he explored the Hunter Valley, and made an insightful contribution to the then controversial issue of the age of the Australian coal measures.

He was a profoundly religious man, and wrestled with Darwin's views on the changing nature of species. He finally agreed with Darwin, much to Darwin's relief, but he did retain much of his religion. He remained a Christian, but a number of manuscripts show his struggle to reconcile a benign Creator with his own understanding of earth history.

Dana was a musician too: he played both the guitar and the flute, he wrote hymns and love songs. And he it was who set some parts of Palmer's poem to music. In Thulia, the settings for guitar of four verses of The Antarctic Mariner's Song were published in the original volume (see below). ${ }^{13}$ But Dana's contribution to the life of the expedition was more than this; his compilation of a songbook which apparently remains unpublished - contains more settings of Palmer's poetry, including the Jolly Old Peacock.

10 Charles Darwin, letter to James Dana, quoted in Louis V Pirsson (1919) ‘Biographical memoir of James Dwight Dana 1813-1895'. US National Academy of Sciences, Biographical Memoirs 9: 41-92, p. 75.

11 Ann Mozley (1966) James Dwight Dana (1813-1895). Australian Dictionary of Biography, vol. 1, Melbourne University Press; available at http://adb.anu.edu.au/biography/dana-james-dwight-1953.

12 James Dana, quoted in Ann Mozley (1964) 'James Dwight Dana in New South Wales, 1839-1840'. Journal and Proceedings of the Royal Society of New South Wales 97: 185-91.

13 Palmer (1843) Thulia: a tale of the Antarctic, pp. 42-6. 


\section{( ${ }^{\circ}$ ANTARCTIC MARINER'S SONG. Pasco 28.}

This song was set to the following music, and arranged for the Guitar, by Mr. JAmes D. DANA, Geologist to the U.S. Exploring Expedition.
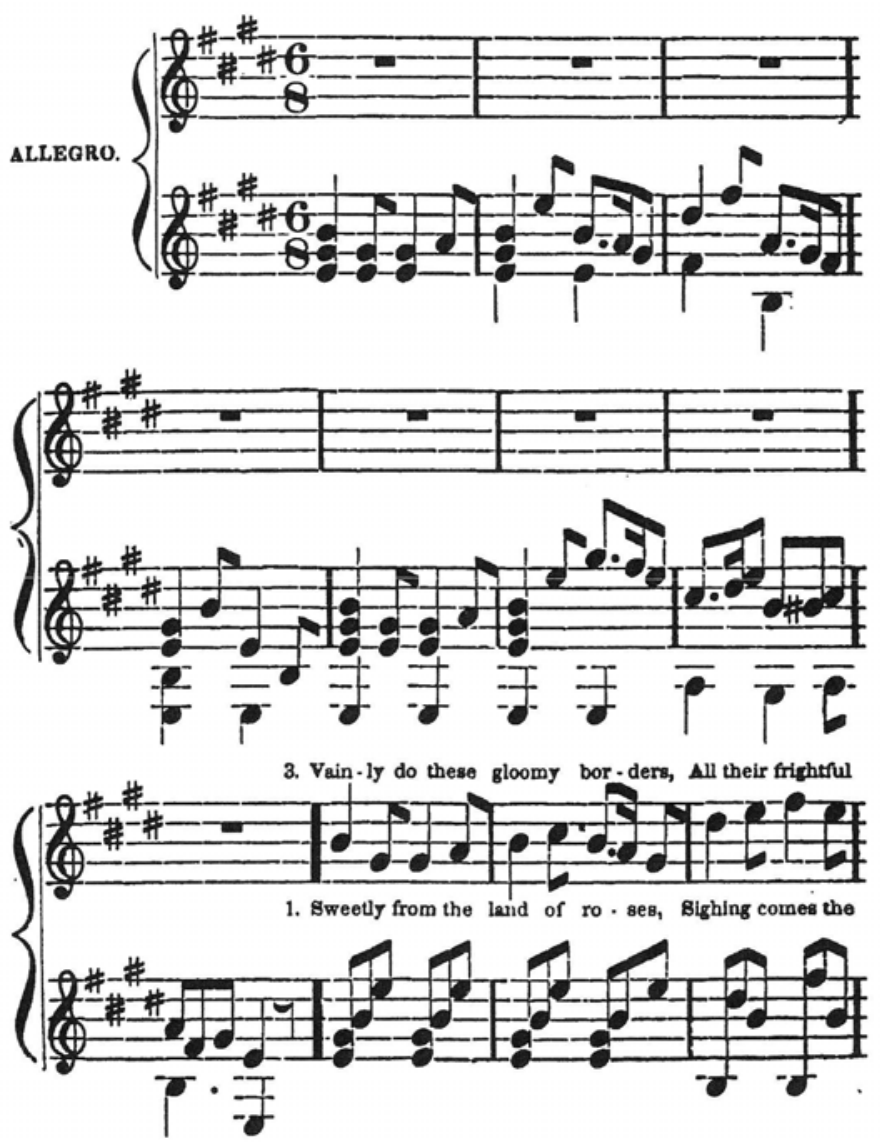

Figure 3. Musical score: Thulia (1843). 


\section{Performance}

It is impossible to know how the musical ballads would have been sung in the 1840s - nor how often, or who the audiences might have been. The poem itself, however, seems to have reasonably popular, and Lenz quotes a number of reviews in contemporary magazines.

In recent years, some of the songs have had a limited number of performances. In 1985 the Smithsonian Institute had some of them performed to commemorate the Wilkes Expedition, since artefacts from that expedition formed much of the original Smithsonian collections.

More recently, at an open day in 2009 held by the US Geological Survey, both the sea shanty The Jolly Old Peacock and parts of the Antarctic Mariner's Song were performed by a small group of musicians. According to the news article reporting this performance, ${ }^{14}$ Dana's 56-page songbook included a full Nativity, the two Antarctic songs, and others about Oregon and his personal life. The 'lyrics' were those of James Palmer, and probably include some of the poems added in the Antarctic Mariner's Song of 1868. The songbook was never published, nor was it mentioned in the formal logs of the expedition. It is reported to have been held by the Palmer family until recently, when it was sold to a private collector. Access to the songbook was instigated by Alan Cooper, an emeritus geologist to the US Geological Survey, a musician himself, and well known to Australian Antarctic scientists. The notes on that performance say that the songs were performed in the 1840s style of the original music manuscripts. Charles Wilkes was the first to assert that Antarctica was a continent, taking upon himself as commander the defence of this claim in the narrative of the voyage. ${ }^{15}$ There is a delicious irony then in the fact that the nature of that landmass should have been first revealed not by Wilkes himself, but by an assistant surgeon in the form of a romantic poem written during the voyage, and set to music by one of the distrusted 'scientifics'.

14 USGS News 13 May 2009, http:// www.usgs.gov/newsroom/article.asp?ID=2219.

15 Charles Wilkes (1844) Narrative of the United States Exploring Expedition during the years 1838, 1839, 1840, 1841, 1842, vols 1-5. C Sherman, Philadelphia. 
This text is taken from Antarctica: Music, sounds and cultural connections, edited by Bernadette Hince, Rupert Summerson and Arnan Wiesel, published 2015 by ANU Press, The Australian National University, Canberra, Australia. 